http://dx.doi.org/10.11646/phytotaxa.141.1.2

\title{
Criscianthus, a new genus of Eupatorieae (Asteraceae) with a key to members of the tribe in Africa
}

\author{
MARIANA A. GROSSI ${ }^{1,3}$, LILIANA KATINAS ${ }^{1} \&$ JIMI N. NAKAJIMA ${ }^{2}$ \\ ${ }^{I}$ División Plantas Vasculares, Museo de La Plata, 1900 La Plata, Argentina. \\ ${ }^{2}$ Instituto de Biologia, Universidade Federal de Uberlândia, Caixa Postal 593, Uberlândia, Minas Gerais, Brasil \\ E-mail: grossi@fcnym.unlp.edu.ar (corresponding author). \\ E-mail:katinas@fcnym.unlp.edu.ar \\ E-mail:nakajima@ufu.br
}

\begin{abstract}
Stomatanthes zambiensis is segregated from the African genus Stomatanthes and raised as the only species of the new genus Criscianthus (Eupatorieae, Asteraceae). Criscianthus zambiensis is characterized by its verticillate phyllotaxy with three leaves per node, phyllaries with caudate apex, and an exclusive type of hair in its cypsela. A full description of the genus and its species, a morphological analysis, photographs, illustrations, and a distribution map are provided. A key to native and alien species of the tribe Eupatorieae in Africa is included.
\end{abstract}

\section{Resumen}

Se segrega a Stomatanthes zambiensis del género africano Stomatanthes y se eleva como la única especie del nuevo género Criscianthus (Eupatorieae, Asteraceae). Criscianthus zambiensis se caracteriza por su filotaxis verticilada con tres hojas por nudo, filarias con el ápice caudado y un tipo exclusivo de pelo en su cipsela. Se incluye una descripción completa del género y de su especie, un análisis morfológico, fotografías, ilustraciones y un mapa de distribución. También se incluye una clave de las especies nativas y adventicias de Eupatorieae en África.

Key words: African Eupatorieae, Eupatoriinae, morphology, Stomatanthes

\section{Introduction}

Generic circumscription and the number of accepted genera within the tribe Eupatorieae (Asteraceae) has changed significantly over the last 45 years. Most of the species of the tribe were once classified as Eupatorium Linnaeus (1753: 836). Between 1967 and 1986 in a series of papers of Robert M. King and Harold Robinson (King \& Robinson 1987) the genus was split into ca. 100 new genera, mainly on the basis of micromorphological (i.e., microscopically observed) characters. Currently the tribe consists of 17 subtribes, 182 genera, and ca. 2200 species concentrated in the Americas with few representatives in the Old World (Hind \& Robinson 2007).

The subtribe Eupatoriinae, as defined by King \& Robinson (1987) and Hind \& Robinson (2007), would comprise four genera: Austroeupatorium King \& Robinson (1970a: 433; 13 species), Eupatorium (ca. 45 species), Hatschbachiella King \& Robinson (1972: 393; two species), and Stomatanthes King \& Robinson (1970a: 430; 17 species). Some authors (Schmidt \& Schilling 2000 sub Eupatoriadelphus, Lamont 2004, Siripun \& Schilling 2006) consider also the genus Eutrochium Rafinesque (1836: 78; five species) as a member of the subtribe whereas other authors (e.g., Hind \& Robinson, 2007) do not recognize it. 


\section{Acknowledgements}

We are grateful to Gisela Sancho and Walter Holmes for comments, to the editor and reviewers for their suggestions, and to the curators of herbaria, especially Vicki Funk from US and Nicholas Hind from K. M.A.G and L.K. acknowledge Consejo Nacional de Investigaciones Científicas y Técnicas (CONICET, PIP 5604), Agencia Nacional de Promoción Científica y Tecnológica (ANPyCT, PICT 01977), and Facultad de Ciencias Naturales y Museo, Universidad Nacional de La Plata. J.N.N. thanks CAPES (BEX 9611/12-6) and CNPq (REFLORA proc. 563541/2010-5). This paper represents a part of the PhD thesis of M.A.G.

\section{References}

Abdallah, J.M. \& Monela, G.G. (2007) Overview of Miombo woodlands in Tanzania. Working papers of the Finnish Forest Research Institute 50. Proceedings of the First MITMIOMBO Project Workshop, Morogoro, Tanzania, 23 pp.

Burman, N.L. (1768) Flora indica: cui accedit series zoophytorum Indicorum nec non prodromus Florae Capensis. Cornelium Haek. \& Johannem Schreuderum, Amsterdam, 241 pp.

Burrows, J.E. \& Willis, C.K. (2005) Plants of the Nyika Plateau: an account of the vegetation of the Nyika National Parks of Malawi and Zambia. Southern African Botanical Diversity Network Report No. 31. SABONET, Pretoria, $405 \mathrm{pp}$.

Buscalioni, L. \& Muschler, R. (1913) Beschreibung der von Ihrer Königlichen Hoheit der Herzogin Helena von Aosta in Zentral-Afrika gesammelten neuen Arten. Botanische Jahrbücher für Systematik, Pflanzengeschichte und Pflanzengeographie 49: 457-515.

Candolle, A.P. de (1836) Prodromus Systematis Naturalis Regni Vegetabilis 5. Sumptibus Sociorum Treuttel et Würtz, Paris, $706 \mathrm{pp}$.

DEEDI (Department of Employment, Economic Development and Innovation) (2011) Mikania vine, Mikania micrantha. Fact sheet PP 143, 4 pp. Queensland Government, Australia. Available from: www.daff.qld.gov.au/documents/ Biosecurity_EnvironmentalPests/IPA-Mikania-Vine-PP143.pdf (accessed: 20 Jan 2013).

Forster, J.R. \& Forster, G. (1772-1775) Characteres Generum Plantarum, quas in itinere ad insulas maris Australis: collegerunt, descripserunt, delinearunt, annis 1772-1775. Prostant apud B. White, T. Cadell, \& P. Elmsly, London, 150 pp.

Freire, S.E. \& Katinas, L. (1995) Morphology and ontogeny of the cypsela hairs of Nassauviinae (Asteraceae, Mutisieae). In: Hind, D.J.N., Jeffrey, C. \& Pope, G.V. (eds.) Advances in Compositae Systematics. Royal Botanic Gardens Kew, London, pp. 107-143.

Grossi, M.A. (2011a) Revisión sistemática, análisis cladístico y biogeografía del género Stomatanthes R.M. King \& H. Rob. (Asteraceae, Eupatorieae). PhD thesis, Facultad de Ciencias Naturales y Museo, Universidad Nacional de La Plata, La Plata, Argentina, 249 pp.

Grossi, M.A. (2011b) Neotypification of Stomatanthes helenae (Buscal. \& Muschl.) Lisowski (Asteraceae): The curious history of an African specimen. Candollea 66: 361-366. http://www.ville-ge.ch/cjb/publications/cando662/C662_361-366.pdf

Grossi, M.A. \& Katinas, L. (2013) A new circumscription of the genus Stomatanthes (Asteraceae, Eupatorieae). Systematic Botany, in press.

Grossi, M.A. \& Nakajima, J.N. (2009) Stomatanthes reticulatus (Asteraceae), a new species from Brazil. Annales Botanici Fennici 46: 443-446. http://www.sekj.org/PDF/anb46-free/anb46-443.pdf

Harris, J.G. \& Woolf Harris, M. (1994) Plant identification terminology. An illustrated glossary. Spring Lake Publishing, Utah, $206 \mathrm{pp}$.

Hess, R. (1938) Vergleichende Untersuchungen über die Zwillingshaare der Compositen. Botanische Jahrbücher fur Systematik, Pflanzengeschichte und Pflanzengeographie 68: 435-496.

Hind, D.J.N. \& Robinson, H. (2007) Tribe Eupatorieae Cass. (1819). In: Kubitzki, K. (ed.) The families and genera of vascular plants 7. Springer-Verlag, Berlin \& Heidelberg, pp. 510-574.

Holmes, W.C. (1982) Revision of the Old World Mikania (Compositae). Botanische Jahrbücher für Systematik, Pflanzengeschichte und Pflanzengeographie 103: 211-246.

Holmgren, P.K., Holmgren, N.H. \& Barnett, L.C. (1990) Index Herbariorum, Part I: The herbaria of the world, 8th ed. New York Botanical Garden, Bronx, 693 pp.

Humbert, H. (1960) Famille Composées. Flores de Madagascar et des Comores 1. Museum d'Histoire Naturelle, Paris, $339 \mathrm{pp}$.

Hyde, M.A., Wursten, B.T. \& Ballings, P. (2013) Flora of Zimbabwe: Home page.

Available from: http://www.zimbabweflora.co.zw/index.php. (accessed: 25 Jan 2013). 
Ito, M., Watanabe, K., Kita, Y., Kawahara, T., Crawford, D.J. \& Yahara, T. (2000) Phylogeny and phytogeography of Eupatorium (Eupatorieae, Asteraceae): Insights from sequence data of the nrDNA ITS regions and cpDNA RFLP. Journal of Plant Research 113: 79-89. http://dx.doi.org/10.1007/PL00013913

IUCN (2010) The IUCN red list of threatened species, version 2010.4. IUCN Red List Unit, Cambridge U.K. Available from: http://www.iucnredlist.org/ (accessed: 15 Jan 2013).

King, R.M. \& Robinson, H. (1970a) Studies in the Eupatorieae (Compositae). XXIV. A new genus Stomatanthes. Phytologia 19: 429-430.

King, R.M. \& Robinson, H. (1970b) Eupatorium, a composite genus or Arcto-Tertiary distribution. Taxon 19: 769-774. http://dx.doi.org/10.2307/1219289

King, R.M. \& Robinson, H. (1970c) Studies in the Eupatorieae (Compositae). XXIX. The genus Chromolaena. Phytologia 20: 196-209.

King, R.M. \& Robinson, H. (1972) Studies in the Eupatorieae (Asteraceae): LXXI. A new genus, Hatschbachiella. Phytologia 23: 393-394.

King, R.M. \& Robinson, H. (1975) New species of Stomatanthes from Africa (Eupatorieae, Compositae). Kew Bulletin 30: $463-465$. http://dx.doi.org/10.2307/4103070

King, R.M. \& Robinson, H. (1987) The genera of the Eupatorieae (Asteraceae). Monographs in Systematic Botany from the Missouri Botanical Garden 22: 1-581.

Kuntze, K.E.O. (1891) Revisio Genera Plantarum con Enumeratione Plantarum Exoticarum in Itinere Mundi Collectarum 1. A. Felix, Leipzig, 374 pp.

Lamont, E. (2004) New combinations in Eutrochium (Asteraceae: Eupatorieae), an earlier name than Eupatoriadelphus. Sida 21: 901-902.

Leaf Architecture Working Group (1999) Manual of leaf architecture-morphological description and categorization of dicotyledonous and net-veined monocotyledonous Angiosperms. Printed privately, Smithsonian Institution, Washington, DC, 65 pp.

Linnaeus, C. (1753) Species Plantarum exhibentes plantas rite cognitas ad genera relatas cum differentiis specificis, nominibus trivialibus, synonymis selectis, locis natalibus, secundum systema sexuale digestas. Impensis L. Salvii, Holmiae, $1200 \mathrm{pp}$.

Linnaeus, C. (1759) Systema naturae per regna tria naturae: secundum classes, ordines, genera, species, cum characteribus, differentiis, synonymis, locis 2. Impensis L. Salvii, Holmiae, 559 pp.

Lisowski, S. (1991) Les Asteraceae dans la flore d'Afrique central (excl. Cichorieae, Inuleae et Vernonieae) 2. Fragmenta Floristica et Geobotanica 36 (Suppl. 1): 251-627.

Macanawai, A.R. (2011) Mikania micrantha: An invasive weed species. Technical Bulletin $\mathrm{n}^{\circ} 3$. Department of Agriculture, Suva, Fiji, 4 pp.

Muniappan, R.A., Raman, A. \& Reddy, G.V.P. (2009) Ageratina adenophora (Sprengel) King and Robinson (Asteraceae). In: Muniappan, R.A., Reddy, G.V.P. \& Raman, A. (eds.) Biological Control of Tropical Weeds using Arthropods. Cambridge University Press, Cambridge, pp. 63-73. http://dx.doi.org/10.1017/CBO9780511576348.004

Oliver, D. (1877) Flora of Tropical Africa 3. Crown Agents for Overseas Governments and Administrations, London, 544 pp.

Orchard, A.E. (2011) A review of Australian Adenostemma J.R. Forst. \& G. Forst. (Asteraceae: Eupatorieae). Telopea 13: 341-348.

Paterson, J.D. \& Zachariades, C. (2013) ISSRs indicate that Chromolaena odorata invading southern Africa originates in Jamaica or Cuba. Biological Control 66: 132-139. http://dx.doi.org/10.1016/j.biocontrol.2013.04.005

Phiri, P.S.M. (2005) A checklist of Zambian vascular plants. Southern African Botanical Diversity Network Report $\mathrm{n}^{\circ} 32$. SABONET, Pretoria, 169 pp.

Rafinesque, C.S. (1838) New Flora and Botany of North America 4. Printed for the author and publisher, Philadelphia, 420 pp.

Ramayya, N. (1962) Studies on the trichomes of some Compositae I. General structure. Bulletin of the Botanical Survey of India 4: 177-188.

Retief, E. (2002) The tribe Eupatorieae (Asteraceae) in southern Africa. In: Zachariades, C., Muniappan, R. \& Strathie, L.W. (eds.) Proceedings of the Fifth International Workshop on Biological Control and Management of Chromolaena odorata, October 2000. Durban, South Africa, pp. 81-89.

Robinson, B.L. (1934) Mikania scandens and its near relatives. Contributions from the Gray Herbarium of Harvard University 104: 55-71.

Schilling, E.E. (2011) Hybrid genera in Liatrinae (Asteraceae: Eupatorieae). Molecular Phylogenetics and Evolution 59: $158-167$. 
http://dx.doi.org/10.1016/j.ympev.2011.01.011

Schmidt, F.W. (1795) Linnee's Neunzehnte Klasse, erste Ordnung: Syngenesia, Polygamia aequalis, semiflosculosi. Sammlung Physikalisch-okonomischer Aufsatze 1: 251-286.

Schmidt, G.J. \& Schilling, E.E. (2000) Phylogeny and biogeography of Eupatorium based on nuclear ITS sequence data. American Journal of Botany 87: 716-726. http://dx.doi.org/10.2307/2656858

Schultz Bipontinus, K.H. (1850) Fleischmannia. Flora 33: 417-418.

Siripun, K.C. \& Schilling, E.E. (2006) Molecular confirmation of the hybrid origin of Eupatorium godfreyanum (Asteraceae). American Journal of Botany 93: 319-325. http://dx.doi.org/10.3732/ajb.93.2.319

Spach, E. (1841) Histoire Naturelle des Végétaux. Phanérogames 10. Librairie Encyclopedique de Roret, Paris, 572 pp.

Udvardy, M.D.F. (1975) A classification of the biogeographical provinces of the world. IUCN Occasional Paper no. 18. IUCN, Morges, Switzerland, 49 pp.

White, F. (1983) The vegetation of Africa, a descriptive memoir to accompany the UNESCO/AETFAT/UNSO Vegetation Map of Africa (3 Plates, Northwestern Africa, Northeastern Africa, and Southern Africa, 1:5,000,000). UNESCO, Paris, $356 \mathrm{pp}$.

Willdenow, C.L. von (1804) Species Plantarum, editio quarta 3(3). Impensis G. C. Nauk, Berlin, 932 pp.

Zachariades, C. \& Goodall, J.M. (2002) Distribution, impact and management of Chromolaena odorata in southern Africa. In: Zachariades, C., Muniappan, R.A. \& Strathie, L.W. (eds.) Proceedings of the Fifth International Workshop on Biological Control and Management of Chromolaena odorata, October 2000. Durban, South Africa, pp. 34-39. 